\title{
Introducing Students with Lexical Bundles to Improve Academic Writing: Students' Learning Experiences and Perceptions
}

\author{
Sri Wuli Fitriati1, Sri Wahyuni2 \\ \{SriWuli.Fitriati@mail.unnes.ac.id. ${ }^{1}$, sriwahyunifbs@mail.unnes.ac.id $\left.{ }^{2}\right\}$ \\ 1,2 Universitas Negeri Semarang, Sekaran Campus, Gunungpati, Semarang, Indonesia
}

\begin{abstract}
This paper aims at explaining the experiences and perceptions of a group of senior EFL students concerning the teaching of lexical bundles to improve coherence in their writings. Students' writings in this study refer to Review of Previous Studies section of a final project. The students are at the eight and tenth semester at the English language education study program at a university in Central Java, Indonesia. Research questions focus on how students describe their experiences in learning lexical bundles for their academic writing and how students perceive the impact of lexical bundles on their writing coherence. The data were collected through focus group discussion, interviews, classroom observations, field notes, a questionnaire with open-response items, and document review. This study makes a significant contribution to the teaching of academic writing in English as a foreign language (EFL) context by providing more in-depth insight into the process of students learning to write Review of Previous Studies by employing lexical bundles according to the discourse functions.
\end{abstract}

Keywords: EFL students, academic writing, coherence, lexical bundles, Review of Previous Studies.

\section{INTRODUCTION}

Commonly, learners of English as a foreign language encounter some difficulties in writing an academic text in English. It might happen due to various reasons, such as lack of students' interest, lack of English language exposure, lack of awareness of the importance of writing skills, and lack of knowledge and practices in writing. Some researchers conducted studies about these phenomena and reported that learners faced difficulties in writing compositions [1], in teaching and learning writing [2] and in writing written works [3]. Challenges in developing coherence in writing can be overcome by having adequate competence in multi-word expressions known as clusters, chunks, or bundles.

Lexical bundles are defined by Biber, Johansson, Leech, Conrad, and Finegan [4] as recurrent expressions, regardless of their idiomaticity and their social status. That is, lexical bundles are simply sequences of word forms that commonly go together in natural discourse. Several studies have shown that the knowledge of lexical bundles marks a higher level of proficiency than the understanding of individual words [5], [6], [7]. Lexical bundles are also considered as the main factor in building fluency in academic discourse, helping to shape meanings and coherence in a text [8]. Lexical bundles are so common and perform discourse 
functions. Therefore, they are essential to the writing and the comprehension of academic writing [9].

A text can be considered coherent when it makes sense. Thornbury [10] defines coherence as the capacity of a text to make sense. In other words, a coherence text means the messages conveyed in the text must be logic and can be accepted. Thus, introducing lexical bundles is essential to improve students' writing skills, especially in achieving coherence. This study aims at explaining students' experiences in learning lexical bundles, how students perceive the impact of lexical bundles on their writing coherence, as well as exploring the strengths and weaknesses of the teaching of lexical bundles.

The use and functions of lexical bundles in spoken and written texts have been widely investigated. It has become an interesting research topic for some linguists and language educators for its role in developing coherent texts. Studies on lexical bundles have mostly employed discourse analysis to analyze their function and use in various registers. However, as far as we concern, the pedagogical implications of this research have been little further explored in the teaching of English in classrooms. That means that research that focuses on how the application of the use of lexical bundles in improving and developing students' use of the English language is still limited. Some researchers are conducting studies using an experimental research design to discover the effect of teaching lexical bundles on students' writing. For example, Ranjbar, Pazhakh, and Gorjian [7] conducted experimental research on two groups of students, an experimental group and a control group. The participants were ninety students selected randomly from the study program of TEFL (Teaching English as a Foreign Language) at Islamic Azad University of Dehloran, Iran. The experimental group was taught lexical bundles taken from a textbook True of Life, while the control group was taught not by using the textbook. In one semester, the students got the treatment. The posttest showed that the teaching of lexical bundles in the experimental group was effective in improving the students' fluency in paragraph writing production.

Aragi, Oskuee, dan Salehpour [11] carried out experimental research on students learning TOEFL (Test of English as a Foreign Language) at the advanced level at Goldis Language Institute, Iran. 45 of 75 students of a TOEFL preparation program were chosen randomly and divided into two groups: experimental and control. After 20 meeting sessions, the two groups were given five essay assignments. The result showed that the experimental group was better in writing essays than the control group because the former was taught lexical bundles while the latter was not. This result implies that the teaching of lexical bundles was a useful technique to improve the quality of the students' essays.

Kazemi, Katiraei, dan Rasekh [12] conducted one-group pretest posttest study. They collected the data from students' essays and questionnaires. They were twenty Master's students majoring in TEFL (Teaching English as a Foreign Language). Before and after the treatment, they did a pretest and a posttest, i.e., writing an essay in which the topic was determined by the instructors. During the treatment, they were taught forty lexical bundles which were most relevant and essential in the field of applied linguistics. The result indicated that the given lexical bundles help them improve their writing ability. In her Master's thesis, Islami [13] did a discourse study of the structure and function of lexical bundles in undergraduate dissertations. Her research focused on the use of lexical bundles in literature review chapters. Findings indicate that students' literature reviews in the undergraduate theses were not very good.

Triggered with Cheung [14], who argues that in teaching writing, we need to explicitly teach the writing processes and the specific strategies to enhance students' writing competence, this present study was conducted, mainly focusing on the writing process and approach that is introducing lexical bundles. Lexical bundles, as cohesive devices are essential in academic 
writing. Studies on the influence of teaching and using lexical bundles on writing have emphasized more on the result or product of students' writing. In addition to an improvement in students' writing scores, it is also necessary to gain insights on students' experiences and perceptions in learning lexical bundles and the applicability of using lexical bundles on production fluency, mainly writing Review of Previous Studies of a final project.

\section{METHODOLOGY}

The present paper reports the qualitative phase of a mixed-methods study. The participants were thirteen Indonesian undergraduate students of English language education study program at the eighth and tenth semester at a university in Semarang city, Central Java. They are in progress in writing their final project proposal and the final project. The participation was voluntary. A list containing 60 four-word lexical bundles was selected from the entire list of lexical bundles identified from at least 15 research articles purposefully compiled by the group of the students during the study. The books used for teaching Review of Previous Studies are Panduan Penulisan Karya Ilmiah UNNES 2018 [15], Academic Phrasebank [16], and a guide to APA referencing style 6th edition [17]. The methods of collecting the data were giving students writing tasks, interviewing, distributing the questionnaire, and conducting classroom observation. The product of the writing task is considered as the first draft (before the explicit teaching) and the last selection of their Review of Previous Studies. To discover the students' perceptions, opinions, and attitudes towards the learning of lexical bundles, an open-ended questionnaire, one-to-one interviews, and group discussions were used. The questionnaire was given before and after the treatment. The purpose of the first open-ended questionnaire was to find out the students' background knowledge about Review of Previous Studies and lexical bundles. The use of the second open-ended questionnaire was to discover the students' perceptions, opinions, and attitudes about the teaching and learning of lexical bundles. A classroom observation sheet was also used to document students' behaviour during the writing class. The classroom observation field notes were also made by a colleague who attended the class as a non-participant observer. The interview, open-response-item questionnaire, and classroom observation data were analysed by using thematic analysis [18].

\section{RESULT AND DISCUSSION}

This section is divided into two main findings: students' experiences in learning lexical bundles and students' perceptions about learning lexical bundles.

\subsection{Students' Learning Experiences}

Based on classroom observation notes complemented with one-to-one interviews with the students and group discussions, the findings show that there are at least three themes related to the students' experiences in learning lexical bundles in academic writing workshops, as follows:

\section{a. Learning lexical bundles is a new experience for students}

Most students stated that learning lexical bundles is such an exciting experience because they became aware that there is an alternative strategy to develop coherence in their writing. The students looked enthusiastic in the writing workshops and almost always engaged in inclass activities. They were very active in class discussions. Besides, the students appeared very eager to find examples of lexical bundles in journal articles that were related to their research topics. It is confirmed by Maharani in an interview: 
I just learned lexical bundles in this workshop. I have never learned it in the previous writing courses. After learning lexical bundles, I knew and realized that lexical bundles helped me to connect one idea to other ideas. Before this, I got difficulties how to start writing sentences, organize them into a paragraph, and compare it to other paragraphs so that they could convey my whole ideas (Maharani, interview, 20 June 2019)

\section{b. Explicit teaching of lexical bundles make a better understanding of cohesive devices}

After taking the workshops, all of the students stated that they admitted they had a better understanding of lexical bundles. As defined by Chairunnisa when being asked about the definition of lexical bundles, she could explain clearly:

Lexical bundles are lexical phrases or formulaic sequences that can help a writer make coherent and effective sentences or paragraphs so that readers can easily understand what the writer means (Chairunnisa, interview, 20 June 2019).

It was also supported by other four students who articulated their understanding of lexical bundles as shown in the following extracts:

Lexical bundles are phrases that help writers present their ideas into an academic, structured and more meaningful paragraph. It assists students to flow the sentences smoothly. As a result, it can minimize run-on sentences. It also helps students to enrich vocabulary mastery so that their writings will be more varied (Jeanne, interview, 21 June 2019).

Moreover, the students could show their understanding of lexical bundles by identifying lexical bundles and categorize them based on their discourse functions in Review of Previous Studies section of some journal articles. They were able to classify previous related studies into some themes and then to restructure into a relatively coherent text.

c. Students' attitudes show increasing awareness of the importance of lexical bundles to make writing coherent

There were some differences in quality between the first and the final draft of the students' Review of Previous Studies. The students admitted that at the beginning of writing the first draft of their Review of Previous Studies, they often used the same phrases so that the writing looked monotonous. They used repeated conjunctions to connect one sentence to another. The lack of lexical bundles use in connecting sentences made their texts seemed less coherent. After learning lexical bundles and their use, they became realized that by using lexical bundles appropriately, their writings would sound academic and exciting to read.

\subsection{Students' Perceptions}

In the section that follows, how the students perceive learning lexical bundles is discussed into two prominent perceptions.

\section{a. Perception about the vital function of lexical bundles}

All of the students asserted that they feel that using lexical bundles in writing Review of Previous Studies in their final project is essential to make their texts coherent. Using lexical bundles also would avoid run-on sentences. Prawiro stated: 
Lexical bundles make my writing smoother. I can now connect one paragraph to another paragraph better. Lexical bundles helped improve coherence, and I can minimize run-on sentences (Prawiro, interview, 30 June 2019).

Furthermore, Nurulhuda and Afifah described that lexical bundles would help them create a good starting point for writing a paragraph and connecting sentences within a paragraph:

Lexical bundles are used not only for categorizing our reviews of previous studies into some themes but also relating one report to another (Nurulhuda, interview, 19 June 2019).

Lexical bundles are also used to start a paragraph to direct the reader to the topic of discussion (Afifah, interview, 19 June 2019).

Lexical bundles enable students to create texts which sound academic and look well-structured. This is confirmed by Oktaviani in one interview:

Before combining a sentence with other sentences into a paragraph, a writer should have basic knowledge of how to do coherent writing. One way to make it consistent is by using appropriate lexical bundles. By using suitable lexical bundles, it will help a writer to create a text flows smoothly (Oktaviani, interview, 18 June 2019).

It can be inferred that all students in the workshop have positive perceptions about lexical bundles that they help create the coherence of a text.

\section{b. Perception of the need for explicit teaching about lexical bundles}

Using appropriate lexical bundles made the students' writings achieved the communicative function of the Review of Previous Studies. Acquiring a wide range of lexical bundles extend the students' lexical attainment. The students got a lot of new bundles that made their writings sound more fluent.

Having engaged in the writing workshops, almost all of the students in this present study stated explicitly and implicitly about their expectations for more successful learning academic writing. Some of the students expect that in the future, the writing instructor may use various techniques in teaching lexical bundles, including the use of teaching media.

Some other students expect to have more practice in applying lexical bundles in their writings and having more sessions on discussing their texts. As Afifah stated:

After using lexical bundles to our Review of Previous Studies, there should be some discussions of the writing so that it could solve students' problems related to lexical bundles. (Afifah, interview, 30 June 2019)

In the end, the students stated their hope that learning lexical bundles can be taught both in the courses of Research in TEFL and Academic Writing during Semester V to provide adequate knowledge for students to create a good piece of academic paper.

Based on the findings of this research, there are several pedagogical implications on the teaching of Review of Previous Studies. In the academic writing class, the students should be provided with some model texts before they are assigned to write. As [19] emphasizes that teachers should design writing tasks with intended outcomes of enhancing both disciplinary knowledge learning, and English writing competence, so that students are not simply instructed to write, but are also directed to write with a purpose, and to deal with real issues in their respective disciplines. Then, students should be assisted to understand better and can apply appropriate lexical bundles to convey their corresponding functions. Third, learning lexical bundles should not make students lack attention to other aspects of writing, including writing mechanics, such as capitalization, punctuation, and spelling. 


\section{CONCLUSION}

Having engaged in the workshops on applying lexical bundles in writing Review of Previous Studies, the majority of the students stated their experiences as valuable that could improve their writing skills. They asserted that they felt assisted in developing the Review of Related Literature of their final projects. However, they also expect some matters to make learning more effective. First, they want the writing instructor to group them based on the topics they discussed in their final project. Next, they want to get more practice in using lexical bundles in class and have a discussion afterward. They also hope the instructor can give them more feedback on their writings. Above all, the students assert that they have a better understanding of lexical bundles after taking the workshop. Regarding the impact of lexical bundles on students' writing coherence, the students claimed that lexical bundles helped them connect ideas within each sentence and paragraph.

The teaching of lexical bundles shows some strengths and weaknesses toward students' writing skills. On the one hand, teaching lexical bundles to the students made their writings become structured and sound more academic. Still, on the other hand, overuse, underuse, and misuse of lexical bundles also will affect the quality of their writings. This present study is the beginning, or the introduction of the teaching of cohesive devices called lexical bundles, which are new to the students. Nevertheless, the findings give us some insights into how to teach coherent writing. This study opens for future research to explore alternative techniques in teaching lexical bundles effectively to improve students' writing coherence.

Acknowledgments. This paper is part of a research report of a mixed-methods study funded by Lembaga Penelitian dan Pengabdian Masyarakat/LPPM (Institute of Research and Communitiy Service) of Universitas Negeri Semarang (UNNES), under the scheme of Penelitian Unggulan Perguruan Tinggi Skema Dasar 2019.

\section{References}

[1] M. Kim, "Genre-based approach to teaching writing," HPU TESL Work. Pap. Ser., vol. 4, no. 2, pp. 33-39, 2006.

[2] J. A. Foley, "English in Thailand," RELC J., vol. 36, no. 2, pp. 223-234, 2005.

[3] N. T. Huy, "Problems affecting learning writing skill of grade 11 at Thong Linh High School," Asian J. Educ. Res., vol. 3, no. 2, pp. 56-69, 2015.

[4] D. Biber, S. Johannsson, G. Leech, S. Conrad, and E. Finegan, Longman grammar of spoken and written English. London: Longman, 1999.

[5] L. Vidakovic and F. Barker, "Use of words and multi-word units in skills for life writing examination," Cambridge ESOL researach notes, vol. 41, pp. 7-14.

[6] Y. H. Chen and P. Baker, "Lexical bundles in L1 and L2 academic writing," Lang. Learn. Technol., vol. 14, no. 2, pp. 30-49, 2010.

[7] N. Ranjbar, A. Pazhakh, and B. Gorjian, "The effect of lexical bundles on Iranian EFL learners linguistic production fluency," Int. Educ. Stud., vol. 5, no. 4, 2012.

[8] H. Kashiha and C. S. Heng, "Structural analysis of lexical bundles in university lectures of politics and chemistry," Int. J. Appl. Linguist. English Lit., vol. 3, no. 1, pp. 224-230, 2014.

[9] W. Pang, "Lexical bundles and the construction of an academic voice: A pedagogical perspective," Asian EFL J., vol. 47, no. 1, pp. 30-34, 2010.

[10] S. Thornbury, Beyond the sentence: introducing discourse analysis. Oxford: Macmillan, 
2005.

[11] S. M. Aragi, M. Y. Oskuee, and S. Salehpour, "The effect of pre-teaching extended prefabricated lexical bundles on the writing development of advanced efl learners,", vol.," Int. J. Appl. Linguist. English Lit., vol. 3, no. 2, pp. 214-219, 2014.

[12] M. Kazemi, S. Katiraei, and A. E. Rasekh, "The impact of teaching lexical bundles on improving Iranian EFL students' writing skill," Procedia - Soc. Behav. Sci., vol. 98, pp. 864-869, 2014.

[13] S. A. D. Islami, "Structure and function of lexical bundles in the literature review of undergraduate students' final projects," Universitas Negeri Semarang, 2019.

[14] Y. L. Cheung, "Teaching writing," in English language teaching today: linking theory and practice, W. A. Renandya and H. P. Widodo, Eds. Switzerland: Springer, 2016, pp. 179-194.

[15] Rustono, J. Mujiyanto, R. Hartono, Wagiran, A. Syaifudin, and Surahmat, Panduan Penulisan Karya Ilmiah. Semarang: UNNES Press, 2018.

[16] J. Morley, Academic Phrasebank. Manchester, United Kingdom: The University of Manchester, 2014.

[17] A Guide to APA Referencing Style: 6th Edition. New Zealand: UCOL Universal College of Learning, 2017.

[18] L. S. Nowell, J. M. Norris, D. E. White, and N. J. Moules, "Thematic analysis: striving to meet the trustworthiness criteria," Int. J. Qual. Methods, vol. 16, pp. 1-13, 2017.

[19] Z. Xu, "Teaching academic writing in context," in English language teaching today: linking theory and practice, W. A. Renandya and H. P. Widodo, Eds. Switzerland: Springer, 2016, pp. 195-207.

\section{Authors biodata}

Sri Wuli Fitriati ${ }^{l}$ is an Associate Professor at the English language and literature department, Faculty of Languages and Arts, Universitas Negeri Semarang (UNNES). At present, she is the coordinator of Master's degree program of English language education. Her research interests include discourse studies in relation to the teaching of English as a foreign language.

Sri Wahyuni ${ }^{2}$ is an Assistant Professor at the English language and literature department, Faculty of Languages and Arts, Universitas Negeri Semarang (UNNES). Her research interests include integration of technology in the teaching of English as a foreign language. 